\title{
In the Shadow of the Grand Narrative: Revisiting the Early Holocene of the Northern Adriatic
}

\author{
Barbara Voytek
}

Published online: 4 May 2011

(C) The Author(s) 2011. This article is published with open access at Springerlink.com

\begin{abstract}
In a 1995 article, 'Reviving the Grand Narrative', Andrew Sherratt critiqued stadial models based on binary opposition (Sherratt in J Eur Archaeol 3:1-32, 1995), causing some to question whether the 'post' of 'post-Pleistocene' was an appropriate way to understand the period. This paper uses that critique as a starting point and examines the Early Holocene of Mediterranean Europe, not as the backwater of Pleistocene big-game hunters, but rather as a dynamic period of socioeconomic as well as environmental changes, separate from yet related to both the preceding Epipaleolithic and the ensuing Early Neolithic.
\end{abstract}

Keywords Early Holocene - Mediterranean Europe $\cdot$ Longue durée

\section{Introduction}

I met Andrew Sherratt only once. It was in Philadelphia in the late seventies, at the famous (or infamous) showdown between US New Archaeologists, flying the banner of Lewis R. Binford, and British archaeologists, rallying behind Colin Renfew. All expected the two beacons of distinct thinking to duke it out over the keynote address, given by Colin. However, it did not happen that way and the day ended with much drinking - the Brits brought the Scotch. And that is when I met Andrew Sherratt.

Besides that memorable encounter, however, I benefited, along with many of my cohort, from his research and writing. His work in Hungary was pivotal for me, since I had hoped to conduct research in Eastern Europe (or what was then Eastern Europe), and it was inspiring to find that an English archaeologist could accomplish such invaluable study despite potential problems of politics and language.

A more recent article was the inspiration of this paper: Sherratt's (1995) David Clarke Memorial Lecture, published in the Journal of European Archaeology as 'Reviving the Grand Narrative: Archaeology and long-term change' (Sherratt 1995).

B. Voytek $(\square)$

Archaeological Research Facility, University of California, Berkeley, CA, USA

e-mail: bvoytek@berkeley.edu 


\section{Background}

Research into the Holocene hunter-gatherers of Mediterranean Europe experienced a surge of activity during the late 1980s and 1990s. Several scholars compelled us to view the Early Holocene not as the backwater of Pleistocene big-game hunters, but rather as a dynamic period of socioeconomic as well as environmental changes, separate from yet related to both the preceding Epipaleolithic and the ensuing Early Neolithic (Clark 1991; Radovanović and Voytek 1997; cf. Straus 1996). Along these lines, Andrew Sherratt's critique of the study of the post-Pleistocene argued effectively that it is not necessarily 'post,' but rather, an interstadial, which would be better examined with a model that is founded on historical process rather than binary opposition (Sherratt 1995, p. 27).

In addition to attempts at 'rethinking' the Mesolithic, anthropological and ethnological studies have found their way into archaeological research designs in places where they had not previously been active. This fact, in the case of Italy, caused at least one researcher to argue that a 'paradigmatic shift in current Mesolithic research' had occurred, especially in northeast Italy (Bietti 1991, p. 269). Understandably, these trends are regional and uneven across the archaeological landscape. However, they are irreversible and lead us to examine the results to date and expectations for the future for Early Holocene studies in the Mediterranean.

The period referenced in this account is the ninth to the sixth millennium BP uncalibrated radiocarbon dates (c. 7500-4500 BC calibrated). The geographic area is the northern Adriatic, roughly from the Adige Valley to the Slovenian Karst (Biagi et al. 1993; Biagi and Voytek 1994). The nature of the available data is uneven in this broad region. Recent survey and fieldwork projects, as well as several environmental studies, have been carried out mainly in the alpine and pre-alpine regions, and pollen studies from peat layers in the mountains have painted an excellent picture of environmental change from the Late Pleistocene to the Holocene (Starkel 1992; Cattani 1992; Oeggl and Wahlmüller 1992; Kofler 1992; Alciati et al. 1992). In addition, a number of faunal studies have contributed to this picture (Chaix and Bridault 1992; Tagliacozzo and Cassoli 1992). The major environmental developments of the Holocene, which are highlighted in this work, have been presented, sometimes in detail, in other studies, namely, (a) the increase in forestation and concomitant improvement in soil cover and plant resource variability; and (b) the rise in sea level, loss of coastlines, and fluctuations in inland water levels affecting both marine and riverine habitats and resources (Barker 1996; Flemming 1983; Geddes et al. 1983; Heinz 1990; Šegota and Filipcic 1991; Shackleton and Van Andel 1985; Sordina 1983; cf. Straus 1996; Van Andel 1989, 1990; Whittle 1996; Zvelebil 1994). Related to these environmental developments were changes in the subsistence systems of the human populations as they adapted and in some cases, adopted, strategies to manage the range of new resources (Zvelebil and RowleyConwy 1986, p. 80). Admittedly, the environmental changes were slow in terms of human lifetimes and 'would have been perceived as gradual changes in relative proportions of habitats and resources, not abrupt replacements' (Jochim 1996, p. 358).

At the same time, the interaction between changing environment and changing human behavior can be studied over what has come to be referred to as the longue durée, borrowing the term from the Annales School (Bintliff 1991). Although this is not the place for an analysis of Sherratt's view of the School, it is clear that he shared its perspective when he wrote that 'what seemed to archaeologists to be like events were in reality, slow transformations' (Sherratt 1997, p. 500). For me, Andrew Sherratt was a master at incorporating and encouraging an expanded view of space and time (Yoffee and Sherratt 1993). 
There are two aspects of the longue durée approach that make it attractive and motivate its inclusion as background for this paper. First of these is the way in which time is conceptualized in separate but overlapping spans: the short-term events within an individual lifetime (such as the construction of a fireplace and digestion of a meal in a cave); the medium-term of several generations to several centuries (such as some archaeological cultures for which a fine-tune chronology cannot be set, for example, the Impressed Ware culture); and finally the long-term, which can span one to several thousand years (such as post-Pleistocene geological or environmental changes).

Another positive feature of the Annales approach for archaeological study is its regional perspective. The varied geographic, climatic, and environmental factors which have interplayed with cultural development among the various regions of, in this case, northern Italy, contribute to the difficulty of defining a homogeneous process of post-Pleistocene adaptation. As Sherratt specifically argued, the '...contrast between "Mesolithic" and "Neolithic" ways of life is in fact as much geographical as chronological...' (Sherratt 1997, p. 136). A regional approach incorporates the variable factors, and positions the researcher to compare regions, rather than archaeological cultures. It is to these regions we can now turn.

\section{Alpine and Pre-Alpine Regions}

In northeast Italy, especially in the Adige Valley, researchers have shown that site distribution differs between the Preboreal/Boreal age (c. 7950-5800 cal BC), affiliated with the so-called Sauveterrian chipped stone industry and the later Atlantic period (5800-4500 cal BC), associated with a lithic technological tradition that has come to be called the Castelnovian industry. The break between these two industries is not especially sharp, and their usefulness in supporting a meaningful comparative framework is limited. The basis of comparison continues to be stone tool types, which do not always lend themselves to testing the theories advanced as to the adaptive behavior which formulated them (Jochim 1996, p. 358). However, as mentioned, this situation is benefiting from the increased number of interdisciplinary regional studies.

Such works have shown that in the earlier period the sites were distributed both on alpine valley-bottoms and in the mountains, at altitudes from 1,900 to 2,300 m. In time, the sites on the alpine valley-bottoms remained while the mountain sites became rarer. The change in site distribution has been related to ecological changes through time, accompanying a progressive shift from a cold dry environment to a temperate and more humid woodland (Tagliacozzo and Cassoli 1992, p. 181). The increase in heat and humidity between the Boreal and Atlantic caused the disappearance of ibex and chamois at lower altitudes, while expansion and restocking of oaks and hazel advanced the populations of red deer, roe deer and wild boar in the alpine valleys and plains (Tagliacozzo and Cassoli 1992, p. 190).

The retreat of the caprine habitat thereby affected land use, site distribution, hunting and butchering patterns (Tagliacozzo and Cassoli 1992, p. 188). Faunal evidence examined by Tagliacozzo and Cassoli from three Adige Valley sites (Pradestal, Romagnano III and the Soman Rockshelter) shows that seasonal hunting of caprines continued. However, because of greater distances to climb to hunt these animals, transport became problematic. Butchering and skinning took place at the hunting station to reduce transport costs. Besides the faunal data, there is some evidence, in the form of microwear studies of stone tool use (Lemorini 1992), that helps support the hypothesis that environmental changes played a 
role in the changing tool industries. Four studies can be summarized here: (1) Laghetti del Crestoso is a hunting site, located at 2,000 $\mathrm{m}$ asl. The industry has been described as Late Castelnovian and dated to the Middle Atlantic. Microwear studies have shown that the tools had been used for both hunting and butchering. (2) Lago delle Buse 2 is another hunting site at 2,000 m asl. The industry is classified as Sauveterrian and dated to the Late Boreal/Early Atlantic. Microwear analysis has shown that the tools were used for hunting, butchering and skinning. (3) Rondeneto, at 1,780 m asl, is a hunting camp with Sauveterrian tool types and dated to the Boreal. The microwear study revealed armatures only for hunting and two wood-working tools. (4) Vaiale is a camp at $830 \mathrm{~m}$ asl. The tool types are classified as Sauveterrian and the site is dated to the Boreal. All tools were armatures for hunting. No butchering or other activities took place at this camp (Voytek, nd).

The purpose of this comparison of assemblage function is to demonstrate that technological changes in lithic assemblages can be related to ecological developments affecting human land use during the Holocene if the research design incorporates such analyses.

\section{The Plains}

Research on the Po and Friuli plains has not been as intensive as in the alpine areas, although it too has been gaining momentum over the past decade or so (Biagi and Voytek 1994; Ferrari and Pessina 1992, 1996). Published data from the Po Plain for the Mesolithic are almost nonexistent, while the data from the Friuli Plain have been gathered relatively recently, since the 1970s, mostly from survey (Candussio et al. 1991). One of the few sites to have actually been excavated, is the Biarzo rockshelter (Bressan et al. 1982). According to lithic typology, this site is considered Sauveterrian, as is the site of S. Giorgio di Nogaro. Another site, Muzzana del Turgnano, is associated with early Castelnovian, again on typological grounds. In Friuli, Mesolithic sites are found among the morainic hills, facing basins of glacial origin which had likely been flooded into the Holocene. Examples include the sites of Molin Nuovo, Rive d'Arcano, Corno-Ripudio, Cassacco, Porpetto, and sites along the Torres (Fragiacomo and Pessina 1995, p. 27). An emphasis on water resources, such as fish, aquatic turtle, and water fowl, has been suggested for this area, although the record is poor. The faunal record is decidedly better for the karst sites, discussed below, and I would argue that we can use that data to support claims of an emphasis on water resources elsewhere during the Holocene, for example, on the Po and Friuli plains.

Interestingly, given the limited data at hand, one can still say that the pattern of site distribution does not appear to differ dramatically through time between the Early Mesolithic Sauveterrian and the later Castelnovian in this region. For example, as mentioned, there are sites with what have been called sauveterroide/castelnovian industries located in lacustrine and riverine settings, many from morainic hills facing glacial basins which had likely been Early Holocene lakes. I would mention here that research on Neolithic sites in the plains is much more advanced. Paleobotanical study of plains sites is rather extensive and has led some researchers to argue that 'There was far from the center of the development of agriculture a proto-agricultural society or at least one can say there existed people in possession of notions of edible species and the technology of gathering and storing' (my translation) (Carugati et al. 1996, p. 104).

Interestingly, the locations of the Early Neolithic sites do not differ greatly from those of the Mesolithic. 


\section{The Karst}

Mesolithic occupation in the Trieste karst has been known and studied for almost 60 years, largely due to the efforts of speologists (Cannarella 1984). There are as yet no open sites known from the Italian karst, although a few Mesolithic open sites are known from Slovenia and Istria (Malez 1979; Frelih 1987; Brodar and Osole 1979; Leben 1976, 1988; Turk et al. 1992, 1993; Brodar 1992). To date, research has revealed a similar pattern of Sauveterrian industries associated with the Preboreal/Boreal period and later Castelnovian lithic traditions during the Atlantic. During the earlier period, the hunting of large mammals like red deer and wild boar predominated, with some evidence for gathering land molluscs and river fish. From more recent Atlantic period sites, we find an increased emphasis on gathering marine molluscs and marine fish. In some cases, the number of anatomical remains of marine species is $50 \%$ greater than that of other faunal remains in the cave. The change seems to correspond well with developments in the lithic industries and correlates with environmental changes mentioned earlier, especially the rise in sea level associated with the Holocene (Boschin 2004, pp. 10-11).

Grotta dell'Edera is a karst cave in Italy near Aurisina, at which excavations were carried out between 1969 and 1975. Subsequent excavations took place between 1992 and 2002, with a 2-year hiatus in 1994 and 1995. The work at Edera has revealed a near $4 \mathrm{~m}$ thick sequence comprised of superimposed fireplaces, hearths, cooking floors, and firepits, with occupation layers attributed to the Migration and Roman periods, the Bronze and Copper Ages, the Middle and Early Neolithic, as well as the Sauveterrian and Castelnovian Mesolithic. Water-screening was conducted on all the soil removed from the cave, using a $2 \mathrm{~mm}$ mesh screen. As a result, we have been able to collect archaeological evidence, including the smallest of specimens such as microfauna, fish bones, charred seeds, and land snails, as well as artifacts including microliths and debitage. The excavation was carried out following the natural stratigraphic layers, which are designated by numbers and letters. Each layer has been further subdivided into horizontal unit levels ('spits') of $10 \mathrm{~cm}$ thickness in order to better appreciate the variability of human activity within each layer. The variations in texture and nature of the sediment at Edera are easily observed from layer 3 downwards. The deposit assigned to layer 2 is essentially a fine-grained grey-buff silt, while the deposit of layer 3 is a compact reddish clay (Biagi et al. 2008, pp. 251-260; Boschian 1997).

Two features described here are of particular note:

A hearth/fireplace about one meter in diameter was uncovered in layer 3a (Fig. 1). Associated with the hearth was a Castelnovian lithic assemblage, small in size, 538 artifacts (Biagi et al. 2008, p. 252). In addition, 17 potsherds were also found, associated with the feature. A date of $6700 \pm 130 \mathrm{BP}(\mathrm{GX}-19569)-(\mathrm{c} .5600 \mathrm{cal} \mathrm{BC})$ was found for the fireplace, rather late in the Castelnovian Mesolithic range. Another find of great interest were three sandstone beads, $1.5 \mathrm{~mm}$ in diameter. Since sandstone is unknown in the area, the beads had been made elsewhere and brought to the cave. The pottery is also of nonlocal origin (Spataro 2001).

In terms of faunal remains, there is evidence for hunting red deer, pig and roe deer, but there were also remains of domesticated species, mainly caprines. At the same time specimens of Patella and Monodonta marine shells totally dominate the faunal remains from this feature. As mentioned above, this situation is known from similar cave features of the same age (Biagi and Voytek 1994; Biagi et al. 1993). For example, at the caves of Azzura and Tartaruga, land molluscs had been found associated with earlier levels, while sea molluscs and fishing came to dominate the faunal remains in the later levels associated 


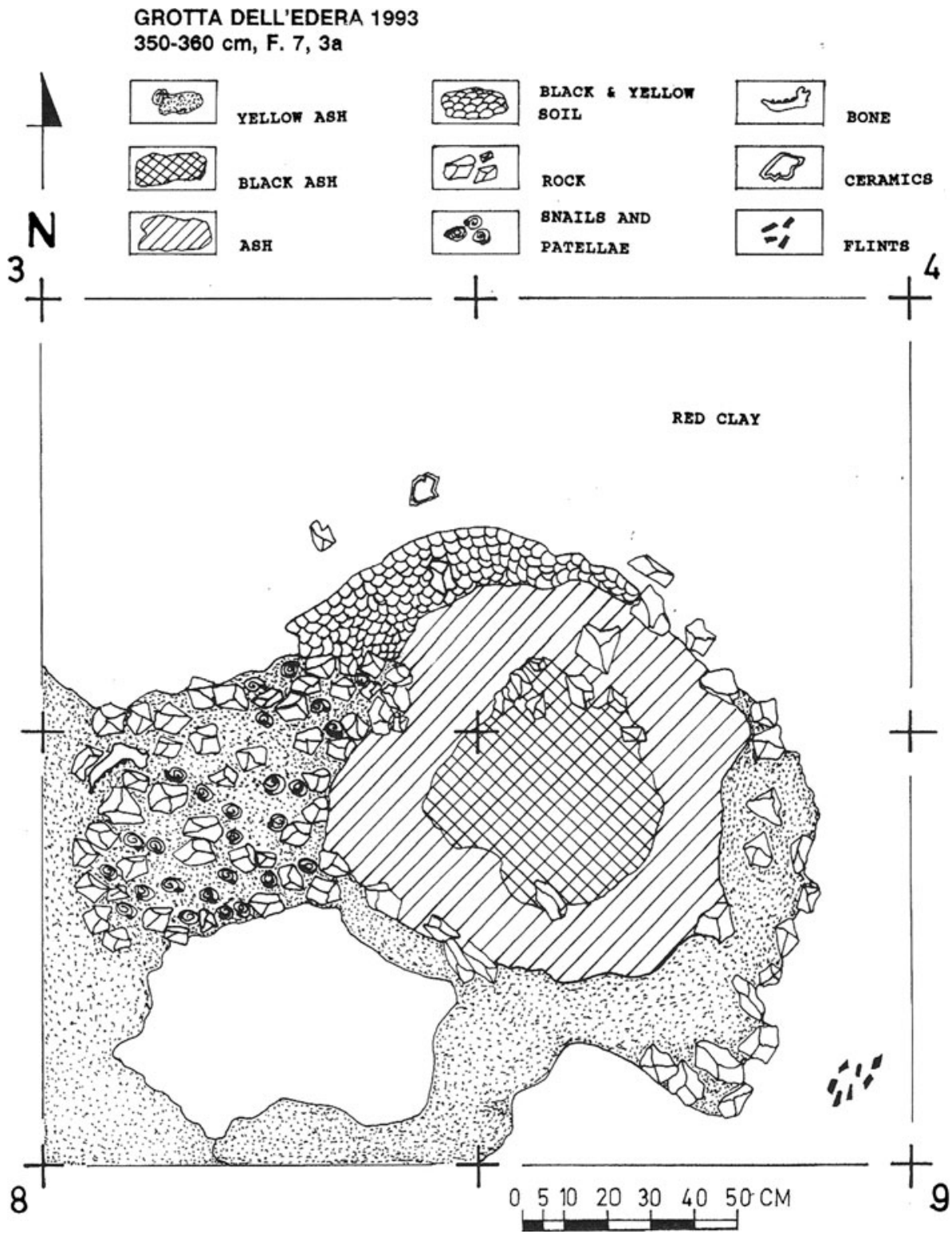

Fig. 1 Grotta dell'Edera, level 3a. Fireplace at 350-360 cm. (drawn by N. Ilic)

with Castelnovian industries (Cannarella 1984, p. 107; Cannarella and Cremonesi 1967). It bears repeating that the dates correspond generally to Holocene changes in sea level due to melting ice sheets, c. 8000-7000 BP.

During the 1997 season at Edera, in layer 3c of the cave, we uncovered what could be described as a living floor with fire pit that was dated $8250 \pm 50$ (GrA 11818); and $8350 \pm 120$ (GrN 25139) (c. $7000 \mathrm{cal}$ ) BC (Fig. 2). The lithic assemblage reflects a Sauveterrian industry with tools having been made on local poor-quality chert-basically 


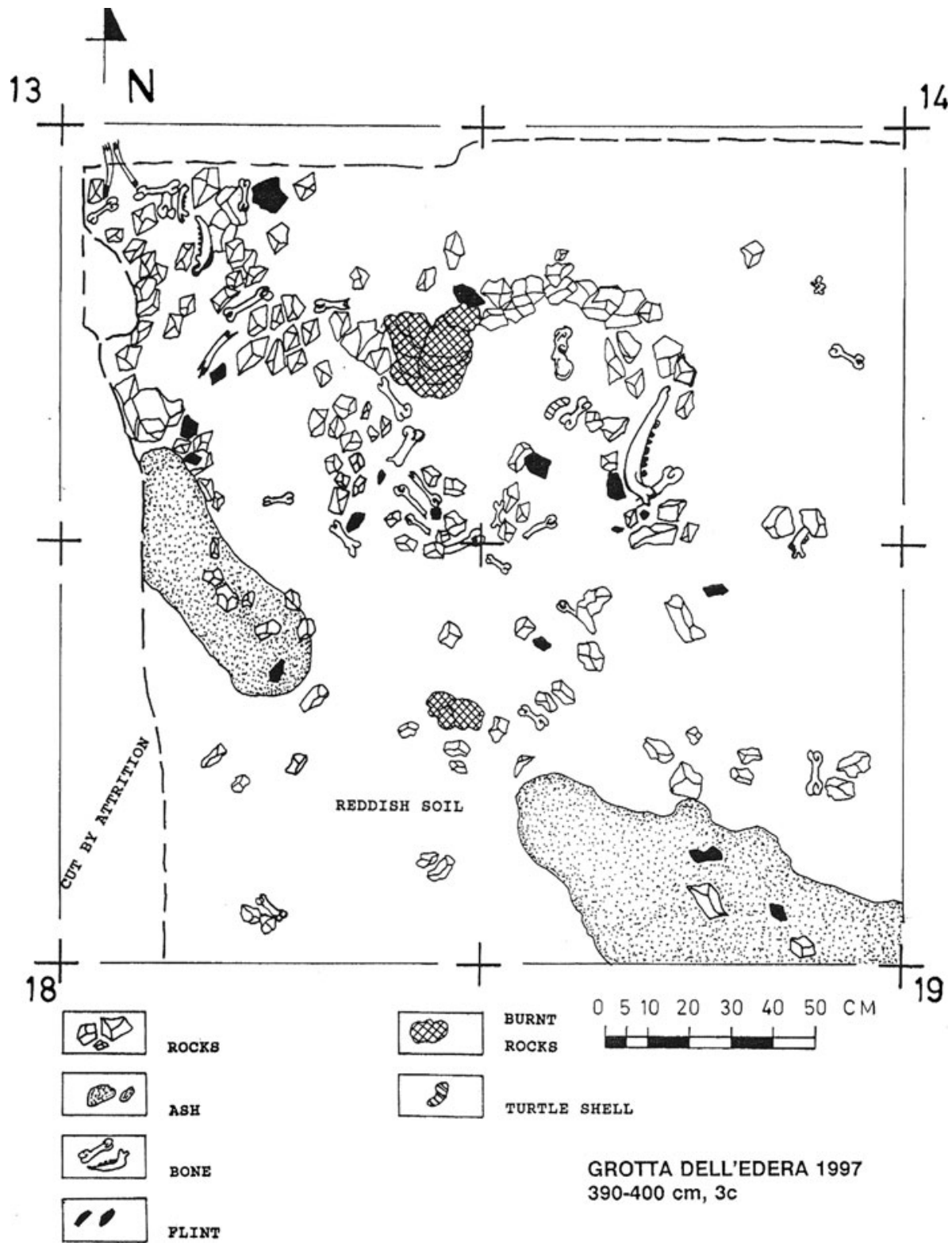

Fig. 2 Grotta dell'Edera, level 3c. Fireplace at 390-400 cm. (drawn by N. Ilic)

bands of black chert found in the local limestone. As a result, the cores are mainly tabular. The tools include long scalene triangles and smaller isosceles triangles (Biagi et al. 2008, p. 253). There is evidence that the limestone had been split to extract the chert, perhaps heating the rocks to facilitate the process. Bone and antler tools were also found on the living floor, often highly polished and/or used.

Analysis of the faunal remains from this layer as well as Boreal/Preboreal layers $3 \mathrm{~b}$ and $3 \mathrm{~d}$ has provided interesting results (Boschin 2004). Perhaps the main characteristic of the 
assemblages is the high index of fragmentation, which is arguably connected to the activities of the early occupiers of the cave. That is, the extensive fragmentation of the bones cannot be exclusively due to natural causes like humidity, soil $\mathrm{pH}$, or thermal changes. Human action also figures here (Boschin 2004, pp. 24, 75). The most numerous species in terms of remains is red deer (Cervus elaphus). In addition, there are found the remains of roe deer, wild boar, mountain goat, ibex, Bos primigenius, badger, otter, fox, marten, dog, wild cat, lynx, bear, hare, beaver, marmot, and hedgehog.

Evidence for butchering was observed on many bones-cutmarks from disarticulation, removing meat from the bone, and fracturing the bone (Boschin 2004, p. 75). An analysis of the microwear of the lithic assemblage from layer $3 \mathrm{c}$ supported these observations since a very high percentage of the used tools (over 50\%) had been used for butchering or scraping and cutting bone. At the same time, the balance of the assemblage showed significant variation in the use of the tools, including wood-working and activities on hides/ skins. In this respect, the feature in $3 c$ differed greatly from that of $3 a$, in which a few specialized activities had been performed, mainly connected with the manufacture of armatures (Biagi et al. 2008, p. 253). The more recent feature suggests a hunting camp, which the living floor of layer $3 \mathrm{c}$ clearly was not. There was good representation of all parts of the animals and sufficient faunal evidence to argue for long-term occupation, even if perhaps not in the winter (Boschin 2004, pp. 75-80).

In addition, there exists a difference in terms of the hearth structures between the two horizons (Biagi et al. 2008, p. 257). That is, in the earlier Boreal horizon, no hearth construction had been undertaken although there was evidence of what might be called a fire pit associated with the remains of red deer and wild boar, as well as debris from stone and bone tool manufacture. The feature appears to represent a clearing or cleaning of the area used by a relatively large group, possibly over some period of time-a fact supported also by the faunal analysis, as mentioned above. The more recent hearth had a stone base and cooking area that reflected some effort on the part of a smaller group of foragers in what had been perceptibly a single episode and shorter use of the space.

Analysis of carbonized plant remains from all levels of the Mesolithic (3a-3d) has shown that climate change through the Holocene had been gradual, with mixed oak and pine forests. Also interesting was the determination that carbonized hazelnuts had been part of the diet of the population that inhabited the cave and created the living floor (Nisbet 2000 , p. 164). Other climate indicators (bones of fresh water fish and tortoise) from the excavations of Edera show that fresh water had been abundant near the cave during the Mesolithic (Delfino and Bressi 2000, p. 123).

We hope that future analyses might shed some light on the potential size of each of the groups responsible for the features, the seasonality of the structures, and potentially the length of use and/or degree of reuse of the fireplaces/hearths (Heinz 1990; Galanidou 1997). A study undertaken by Movius at the Abri Pataud in the early 1960s attempted to differentiate Upper Palaeolithic social groupings through time (Movius 1966). Although the study had some shortcomings (Galanidou 1997, p. 7), it was at that time considered rather innovative. Referencing Andrew Sherratt again, I believe that his observation about '...the long-term significance of the repeated shifts from communal to individual... from TRB to Corded Ware...' (Sherratt 1997, p. 494) has relevance here. That is, the change through time in the usage of the Edera cave reveals changes in social relations during the Mesolithic that were as significant as those which accompanied the earliest food production. 


\section{Conclusion}

There is, in effect, no conclusion to this article since the research is ongoing and the purpose of this work is to illustrate some of the directions being undertaken. With the increased emphasis on Holocene studies of an interdisciplinary and regional nature, I believe that a clear picture will emerge of socioeconomic transformation, with interacting environmental and cultural developments that can be examined over the longue durée. In the northern Adriatic, elements of these developments can be seen and related to a framework of resource management strategies, discussed more than 20 years ago by Zvelebil and Rowley-Conwy (1986): increased residential permanence, logistical use of resources, technological developments, specialized tool kits, pottery, development of trade and exchange, and social elaboration. These strategies have an historical trajectory, and as pointed out by Jochim, responses 'to the environmental changes of this period should vary according to the specific past adaptations of the groups involved' (Jochim 1996, p. 360).

To a certain extent, the past adaptations of the Holocene foragers have tended to be underplayed, almost like a people without history. They fall within a 'transitional' period, and theorists who study transitions tend to look less to origins than to future states when seeking explanations. There have been several archaeological studies of the MesolithicNeolithic transition that can be characterized in this way, and these tend to promote a dichotomy between the two economies, which we would argue becomes less apparent if a sense of the historical trajectory is maintained. I believe that Andrew Sherratt would have argued this as well. One can continue to look to his works for inspiration and a framework in which to do better prehistory.

Acknowledgments Grotta dell'Edera was discovered in 1969 during a survey carried out by the Gruppo Richerche di Paleontologia Umana, Sezione XXX Ottobre, of the Club Alpino Italiano of Trieste. It is catalogued with the number 5134 V.G. Excavations had been under the co-directors Prof. Paolo Biagi, University of Venice (in whose name is the Italian permit), and Dr. Barbara Voytek, University of California, Berkeley; funding has come from the National Science Foundation, Washington, DC; the Stahl Endowment Fund, UC Berkeley; the American Philosophical Society, Philadelphia, PA; the Wenner Gren Foundation, New York; and the Society for the Prehistory and Protohistory of Friuli-Venezia Giulia, Trieste.

Open Access This article is distributed under the terms of the Creative Commons Attribution Noncommercial License which permits any noncommercial use, distribution, and reproduction in any medium, provided the original author(s) and source are credited.

\section{References}

Alciati, G., Cattani, L., Fontana, F., Gerhardinger, E., Guerreschi, A., Milliken, S., et al. (1992). Mondeval de Sora: A high altitude Mesolithic campsite in the Italian Dolomites. Preistoria Alpina, 28(1), 351-366.

Barker, G. (1996). Early Holocene environments and subsistence strategies in the Mediterranean basin. In S. Kozlowski \& C. Tozzi (Eds.), Colloqium XIV, Adaptations to post-glacial environments, vol. 7 of Proceedings of the UISPP XIII Annual Congress, Forli, Italy (pp. 105-112).

Biagi, P., Starnini, E., \& Voytek, B. (1993). The late Mesolithic and early Neolithic settlement of Northern Italy: Recent considerations. Porocilo o Raziskovanju Paleolita, Neolita in Eneolita v Sloveniji, 21, 45-67.

Biagi, P., Starnini, E., \& Voytek, B. (2008). The Mesolithic-Neolithic transition in the Trieste Karst (northeastern Italy) as seen from the excavations at the Edera Cave. In C. Bonsall, V. Boroneant, \& I. Radovanović (Eds.), The Iron Gates in prehistory: New perspectives. BAR International Series, 1893 (pp. 251-260).

Biagi, P., \& Voytek, B. (1994). The neolithisation of the Trieste karst in northeastern Italy and its neighbouring countries. Jósa András Múzeum Évkönyve a Nyiregyhazi, 36, 63-74. 
Bietti, A. (1991). Normal science and paradigmatic biases in Italian hunter-gatherer prehistory. In G. A. Clark (Ed.), Perspectives on the past: Theoretical biases in Mediterranean hunting-gathering research (pp. 258-281). Philadelphia: University of Pennsylvania Press.

Bintliff, J. L. (Ed.). (1991). The Annales School and archaeology. New York: New York University Press.

Boschian, G. (1997). Sedimentology and soil micromorphology of the Late Pleistocene and Early Holocene deposits of Grotta dell'Edera (Trieste Karst, NE Italy). Geoarchaeology, 12(3), 1-23. (mss pages).

Boschin, F. (2004). L'analisi archeozoologica dei resti di macromammiferi provienti dai livelli mesolitici della Grotta dell'Edera (Carso Triestino-Scavi 1990-2001). Laurea thesis, Universita degli Studi di Trieste, Facolta di Scienze Mathematiche, Fisiche, e Naturali.

Bressan, F., et al. (1982). Nuovi data sulla preistoria in Friuli: il Riparo di Biarzo (scavi 1982), S. Pietro ad Natisone (Udine). Gortania, 4, 65-85.

Brodar, M. (1992). Mezolitsko najdišče Pod Crmukljo pri Sembijah. Arheoloski Vestnik, 43, $23-36$.

Brodar, M., \& Osole, F. (1979). Paleolitske i mezolitske regije i kulture u Sloveniji. In A. Benac (Ed.), Praistorija Jugoslavenskih zemalja (Vol. 1, pp. 159-194). Sarajevo: Akademija Nauka i Umjetnosti Bosne i Hercegovine.

Candussio, A., et al. (1991). Nuovi siti mesolitici in provincia di Udine. Natura Bresciana, 26, 251-287.

Cannarella, D. (1984). La storia delle ricerche del mesolitico sul Carso Triestino. Il mesolitico sul Carso Triestino. Atti della Società per la Preistoria e Protostoria della Regione Friuli-Venezia Giulia, 5, 13-20.

Cannarella, D., \& Cremonesi, G. (1967). Gli scavi nella grotta Azzurra di Samatorza. Rivista Sc. Preist. 22, Firenze.

Carugati, M. G., Castelletti, L., \& Rottoli, R. (1996). L’agricoltura nel primo Neolitico del Friuli: le ricerche a Sammardenchia, Fagnigola e Valer. In A. Ferrari \& A. Pessina (Eds.), Sammardenchia e i Primi Agricoltori del Friuli (pp. 103-112). Udine: Banca di Credito Cooperativo di Basiliano.

Cattani, L. (1992). Prehistoric environments and sites in the Eastern Alps during the late glacial and postglacial. Preistoria Alpina, 28(1), 61-70.

Chaix, L., \& Bridault, A. (1992). Nouvelles données sur l'exploitation des animaux sauvages de l'Epipaléolithique au Mésolithique final dans les Alpes du Nord et le Jura. Preistoria Alpina, 28(1), $115-127$.

Clark, G. A. (Ed.). (1991). Perspectives on the past: Theoretical biases in Mediterranean hunter-gatherer research. Philadelphia: University of Pennsylvania Press.

Delfino, M., \& Bressi, N. (2000). L'erpetofauna Olocenica proveniente dalla Grotta dell'Edera (Trieste). Atti della Società per la Preistoria e Protostoria della Regione Friuli-Venezia Giulia, 8, 115-125.

Ferrari, A., \& Pessina, A. (1992). Considerazioni sul primo popolamento neolitico dell'area friulana. Atti della Società per la Preistoria e Protostoria della Regione Friuli-Venezia Giulia, 6, $23-60$.

Ferrari, A., \& Pessina, A. (Eds.). (1996). Sammardenchia e i primi agricoltori del Friuli. Udine: Banca di Credito Cooperativo di Basiliano.

Flemming, N. C. (1983). Preliminary geomorphological survey of an early Neolithic submerged site in the Sporadhes, N. Aegean. In P. M. Masters \& N. C. Flemming (Eds.), Quaternary coastlines and marine archaeology: Towards the prehistory of land bridges and continental shelves (pp. 233-268). London: Academic Press.

Fragiacomo, A., \& Pessina, A. (1995). Industrie litiche da Molin Nuovo (UD) nelle collezioni dei Civici Musei di Udine. Quaderni Friuliani di Archeologia, 5, 23-43.

Frelih, M. (1987). Breg pri Škofljici: Mezolitsko najdišče na Ljubljanskom Barju. Porčlo o Raziskovanju Paleolita, Neolita in Eneolita v Sloveniji, 14, 21-58.

Galanidou, N. (1997). 'Home is where the hearth is': The spatial organisation of the Upper Palaeolithic rockshelter occupations at Klithi and Kastritsa in northwest Greece. BAR International Series 687, Archeopress, Oxford.

Geddes, D., Guilaine, J., \& Monaco, A. (1983). Early Neolithic occupation on the submerged continental plateau of Roussillon (France). In P. M. Masters \& N. C. Flemming (Eds.), Quaternary coastlines and marine archaeology: Towards the prehistory of land bridges and continental shelves (pp. 175-187). London: Academic Press.

Heinz, C. (1990). Dynamique des végétations holocènes en Méditerranée nord-occidentale d'après l'anthracoanalyse des sites préhistoriques: méthodologie et paléoécologie. Paléobiologie Continentale, $16(2), 1-56$.

Jochim, M. A. (1996). Surprises, recurring themes, and new questions in the study of the Late Glacial and Early Postglacial. In L. G. Straus, et al. (Eds.), Humans at the end of the Ice Age: The archaeology of the Pleistocene-Holocene transition (pp. 357-363). New York and London: Plenum Press.

Kofler, W. (1992). Die Vegetationsentwicklung im Spätpalaolithikum und Mesolithikum im Raume Trient. Preistoria Alpina, 28(1), 83-103. 
Leben, F. (1976). The first Adriatic Neolithic in Slovenia. Archaeologia Iugoslavica, 17, 3-7.

Leben, F. (1988). Novoodkrite prazgodovinske plasti v jamah na krasu. Poročilo o Raziskovanju Paleolita, Neolita in Eneolita v Sloveniji, 16, 65-76.

Lemorini, C. (1992). Etude fonctionnelle des industries Mésolithiques de Lago delle Buse 1 et Lago delle Buse 2 (Lagorai, Trentino) par la méthode des traces d'utilisation. Preistoria Alpina, 28(1), 51-59.

Malez, M. (1979). Paleolitsko i mezolitsko doba u Hrvatskoj. In A. Benac (Ed.), Praistorija Jugoslavenskih Zemalja (Vol. 1, pp. 195-295). Sarajevo: Akademija Nauka i Umjetnosti Bosne i Hercegovine.

Movius, H. L. (1966). The hearths of the Upper Perigordian and Aurignacian horizons at the Abri Pataud, Les Eyzies (Dordogne), and their possible significance. American Anthropologist, 68(2), 296-325.

Nisbet, R. (2000). Nota preliminare sull'antracologia dei depositi Olocenici della Grotta dell'Edera, Carso Triestino (scavi 1990-1999). Atti della Società Preistoria e Protostoria Friuli-Venezia Giulia, Trieste, $8,161-170$.

Oeggl, K., \& Wahlmüller, N. (1992). Vegetation and climate history of a high alpine Mesolithic camp site in the Eastern Alps. Preistoria Alpina, 28(1), 71-82.

Radovanović, I., \& Voytek, B. (1997). Hunters, fishers or farmers: Sedentism, subsistence and social complexity in the Djerdap Mesolithic. Analecta Praehistorica Leidensia, 29, 19-31.

Šegota, T., \& Filipčić, A. (1991). Arheološki i geološki pokazatelji Holocenskog položaja razine mora na istočnoj obali Jadranskog Mora. RAD Hrvatske akademije znanosti i umjetnosti, 458, 149-172.

Shackleton, J., \& Van Andel, T. H. (1985). Late Palaeolithic and Mesolithic coastlines of the western Mediterranean. Cahiers Ligures de Préhistoire et de Protohistoire, 2, 7-19.

Sherratt, A. (1995). Reviving the grand narrative: Archaeology and long-term change. Journal of European Archaeology, 3(1), 1-32.

Sherratt, A. (1997). Economy and society in prehistoric Europe: Changing perspectives. Princeton, NJ: Princeton University Press.

Sordina, A. (1983). Quaternary shorelines in the region of Corfu and adjacent islets, western Greece. In P. M. Masters \& N. C. Flemming (Eds.), Quaternary coastlines and marine archaeology: Towards the prehistory of land bridges and continental shelves (pp. 335-344). London: Academic Press.

Spataro, M. (2001). An interpretative approach to the prehistory of the Edera Cave in the Trieste Karst (northeastern Italy): The archaeometry of the ceramic assemblage. Accordia Research Papers, 8, 83-99.

Starkel, L. (1992). Regularities of mountain geosystems. Preistoria Alpina, 28(1), 11-18.

Straus, L. G. (1996). The archaeology of the Pleistocene-Holocene transition in southwest Europe. In L. G. Strauss, et al. (Eds.), Humans at the end of the Ice Age: The archaeology of the PleistoceneHolocene transition (pp. 83-100). New York and London: Plenum Press.

Tagliacozzo, A., \& Cassoli, P. F. (1992). La macrofauna de l'Abri Soman (Val d'Adige - Italie). Preistoria Alpina, 28(1), 181-192.

Turk, I., et al. (1992). Acijev spodmol pri Petrinjah, Slovenija. Poročlo o Raziskovanju Paleolita, Neolita in Eneolita v Sloveniji, 20, 27-48.

Turk, I., et al. (1993). Podmol pri Kaštelcu: Novo večplastno arheološko najdišče na krasu, Slovenija. Arheoloski Vestnik, 44, 45-96.

Van Andel, T. H. (1989). Late Quaternary sea-level changes and archaeology. Antiquity, 63, 733-745.

Van Andel, T. H. (1990). Addendum to 'Late Quaternary sea-level changes and archaeology'. Antiquity, 64, $151-152$.

Voytek, B. (nd). Unpublished report on microwear study of lithic materials from Vaiale, 1991. Brescia, Italy.

Whittle, A. W. R. (1996). Europe in the Neolithic: The creation of new worlds. Cambridge: Cambridge University Press.

Yoffee, N., \& Sherratt, A. (Eds.). (1993). Archaeological theory: Who sets the agenda? Cambridge: Cambridge University Press.

Zvelebil, M. (1994). Plant use in the Mesolithic and its role in the transition to farming. Proceedings of the Prehistoric Society, 60, 35-74.

Zvelebil, M., \& Rowley-Conwy, P. (1986). Foragers and farmers in Atlantic Europe. In M. Zvelebil (Ed.), Hunters in transition: Mesolithic societies of temperate Eurasia and their transition to farming (pp. 67-94). Cambridge: Cambridge University Press. 